\title{
Chapter 3 \\ Earnings Trajectories Following Parental Separation Among First-Time Parents in Sweden
}

\author{
Anna-Karin Nylin
}

\section{Introduction}

A large body of research has focused on various aspects of the transition to parenthood and the transition to becoming a single parent; two life events with longlasting and highly gendered economic consequences. When couples enter parenthood, gender inequalities are often reproduced and reinforced, as women tend to increase the time they spend in care work while decreasing the time they spend in paid work (Evertsson and Boye 2016). This pattern causes the earnings gap between women and men to widen (Musick et al. 2017), even in Sweden, a country known for having high maternal labour force participation rates, a long history of family policy investment, and strong norms of gender equality (Angelov et al. 2016; Nylin et al. 2019). Most of today's single-parent families are the result of a separation of a married or cohabiting couple (Heuveline et al. 2003). In light of these trends, researchers have turned their attention to a wide range of effects that parents as well as children face following a parental separation, including the economic ramifications of separation. Early research on this topic has shown that women experience large declines in household income after divorce and separation, which is generally attributed to a gendered division of labour that existed before the separation (see the review by Holden and Smock 1991). However, later research on this issue has found that men also suffer economically from separation and divorce, which may be due to a drop in earnings related to health impairments following the separation (Brüggmann in this volume). But it appears that some men experience a decrease in household income after a separation because they had interrupted employment after the birth of their first child, or because their female partner was the prime earner in the family (Andreß et al. 2006; McManus and DiPrete 2001).

\footnotetext{
A.-K. Nylin ( $\square)$

Stockholm University, Stockholm, Sweden

e-mail: anna-karin.nylin@ sociology.su.se
} 
This chapter contributes to the large body of literature that has examined gender differences in the economic consequences following parental separation. I focus on the effects of separation on the individual earnings of fathers and mothers. In particular, I investigate the question of how the gendered division of work before separation affects the subsequent earning trajectories of the ex-partners. The data come from a large-scale Swedish register dataset covering the total population. I have chosen to study Sweden in part because it represents a setting in which parental separation is rather common and is less stigmatised than it is in many other countries. Moreover, it is common in Sweden for mothers to participate in the labour force and for fathers to retain a large degree of responsibility for their children postseparation. In addition, Swedish registers cover the whole population, and therefore provide a sample size that is large enough to allow me to longitudinally explore the economic development of coupled women and men as they enter parenthood, and after they separate. These register data thus offer me a unique opportunity to follow family members across households in order to understand subgroup variation. By contrast, panel survey data either do not follow both partners after separation, or follow them with relatively low participation rates.

The analytical sample contains women and men who had their first child between 2002 and 2004, and who were living together at the time of the birth. The earning trajectories of fathers and mothers are investigated up to 8 years after the first birth. I compare men and women who remained partnered with women and men who separated until their first child reached age eight. The latter group is further distinguished by whether separation occurred one, three, or 5 years after the first birth. Earnings are measured in terms of annual earnings in Swedish Krona (SEK). In order to operationalise the gendered division of work before separation, I include a measure for the earnings position 2 years before becoming a parent, measured in earnings quartiles. A caveat of the analysis is that the data do not contain working hours. Another caveat is that re-partnering and its effects on earnings are not examined.

\section{The Swedish Context}

\section{Parental Separation of Married and Cohabiting Couples}

Declining rates of marriage combined with increasing rates of cohabitation and separation have long distinguished Sweden as a forerunner in demographic change. During the 1970s and 1980s, the non-marital childbearing ratio increased, and cohabitation, even among parents, became a common living arrangement in Sweden (Ohlsson-Wijk et al. 2018). It was also during the 1970s that the requirement that 
spouses mutually agree to divorce was removed, and divorce rates started to increase (Hoem 1997). Even though divorce risks had levelled off at the turn of the last century (Andersson and Kolk 2016), divorce remains a common transition among Swedish parents. Moreover, like divorce rates among married couples, separation rates among cohabiting couples have been increasing. Today in Sweden, separation rates among cohabiting parents are only slightly higher than divorce rates among married parents (Thomson 2005). Under Swedish law, the differences between divorcing and dissolving a cohabiting union are small. Thus, the two types of couples have similar social security benefits, legal rights, and economic benefits (Perelli-Harris and Sánchez Gassen 2012); and their child custody rights are the same (Schiratzki 2008).

\section{The Role of the Welfare System}

In Sweden, the female employment rate has long been high, and is currently almost the same as the male employment rate, even among parents (Statistics Sweden [SCB] 2016). This near parity in employment levels is usually ascribed to the Swedish welfare system. Individual taxation promotes female employment (Selin 2014), and women have the legal right to return to their previous employer and position after taking parental leave (Föräldraledighetslag 1995: 584, The Parental Leave Act 1995: 584). The availability of affordable, high-quality public childcare allows mothers and fathers to stay in paid work after having children, and is used by most parents (Swedish National Agency for Education 2018). This comprehensive welfare system has been found to provide parents with more reliable protection against poverty than other welfare systems that do not encourage parental employment to the same extent (Ferrarini 2006). Hence, if women in Sweden separate, they are less economically vulnerable than their counterparts in many other countries, who may be forced to give up paid employment when they enter motherhood. However, even though single mothers in Sweden are less economically vulnerable than single mothers in other countries, their situations have worsened over time (Nieuwenhuis and Maldonado 2018), as their equalized disposable household income levels have been lagging further and further behind those of coupled mothers (SCB, Household's finances 2014). There is evidence that in Sweden, the financial situations of single parents deteriorated more and did not recover as quickly as the financial situations of the rest of the population during the economic crisis in the 1990s. It has also been shown that reductions in social benefits and the enactment of stricter rules for obtaining means-tested benefits affected single parents more than coupled parents. Although the household earnings of single parents improved during the 2000s, the lower means-tested benefit levels have prevented the incomes of single parents from catching up with those of parents in unions (Swedish Social Insurance Agency 2009). 


\section{Prior Research and Hypotheses}

\section{Economic Consequences of Parenthood}

Parenthood has been found to have a negative impact on women's wages (Gangl and Ziefle 2009), even in Sweden (Angelov et al. 2016; Nylin et al. 2019), where policies supporting the dual earner-carer model have been implemented (Gornick and Meyers 2003). When women take time off from work to care for children, their future earnings are often negatively affected, in part because the breaks they take tend to be considerably longer than those taken by men (Duvander and Viklund 2014). In addition, women decrease their paid work hours by almost $10 \%$, on average, after they have children (Kennerberg 2007). Among parents of children between three and 5 years old, one-third of the mothers, but just $10 \%$ of the fathers, are working part time (SCB 2016). Spells of part-time employment can have long-term consequences for an individual's career development and future earnings (Duvander et al. 2015). Using Swedish register data, several studies have shown that there are large gender gaps in income and wages up to 15 years after childbirth, and that women with low educational attainment and earnings are hit harder than other groups (Angelov et al. 2016; Duvander et al. 2015).

The economic approach suggests that parenthood can have a negative impact on wages through various channels. It is, for example, possible that parents are perceived as being less productive (Becker 1993; Budig and England 2001; Mincer and Polacheck 1974). Parents may also be less able than workers without children to invest in on-the-job training (Evertsson 2004). This is especially likely to be the case for women, as they are mainly responsible for childbearing. Thus, in the workplace, women often fall behind men in terms of their experience and compensation levels. While motherhood penalties tend to be smaller in the Nordic countries than they are elsewhere (Sigle-Rushton and Waldfogel 2007), statistical discrimination against all women of childbearing age may explain a portion of the gender differences in wages (Mandel and Semyonov 2005; Ruhm 1998). A tendency for women to take mother-friendly jobs has also been observed in some countries, with women trading higher wages for flexibility (Gangl and Ziefle 2009). By contrast, men have been found to be rewarded with earning premiums after entering parenthood (Cooke 2014; Hodges and Budig 2010; Petersen et al. 2014). There is, however, evidence that when men take even short periods of parental leave, they experience negative wage effects (Albrecht et al. 2015; Evertsson 2016). Signalling theory suggests that employers perceive men who take leave as less committed to their jobs, and penalize them with lower wages (Albrecht et al. 1999; Evertsson 2016). Wage losses after taking time away from work appear to be greatest for the most highly educated women and men (Albrecht et al. 1999; England et al. 2016; Evertsson 2016; Glauber 2018). 


\section{Economic Consequences of Union Dissolution}

A large body of literature has examined the economic consequences of divorce and separation based on longitudinal data. These studies have shown that after a divorce, women tend to suffer economically as their household income declines and their dependency burden grows (see review by Holden and Smock 1991); and that women with children suffer the most (Mortelmans and Defever 2018; Page and Stevens 2004). Later studies have also found that as the female labour market participation rate increases and the gender wage gap decreases, men are also likely to suffer economically following a divorce. Yet on average, the household income levels of men still decline less than those of women following union dissolution (McManus and DiPrete 2001).

To mitigate the negative economic consequences of a separation, parents tend to use a range of personal strategies, called "coping mechanisms" (see Mortelmans in this volume). One of the main strategies parents use to deal with the cost of union dissolution is increasing their own labour earnings (Duncan and Hoffman 1985; McManus and DiPrete 2001; Weiss 1984). The use of this strategy is the core focus of this study. Especially for a single parent with a higher income level, his/her own labour income is usually the most important component of the household's income (McManus and DiPrete 2001; Weiss 1984).

De Vaus et al. (2017) used data from the United States, the UK, Switzerland, Korea, Germany, and Australia to examine the economic consequences of divorce. They showed that the cross-country differences in these consequences can be explained in large part by differences in women's labour earnings. In the countries where women's labour market participation rates tend to be high while married, women's income levels are more likely to recuperate after they separate (de Vaus et al. 2017). However, when mothers work full-time while married or cohabiting, like they often do in Sweden, there is little scope to further increase their employment after they separate. If women have secure working conditions and high earnings, they may instead choose to reduce their work hours or change to a more flexible job in order to better reconcile work and family life (Alsarve et al. 2017). Thus, women might trade higher earnings for having more time with their family.

Another important strategy parents use to mitigate the economic consequences of separation is re-partnering (DiPrete and McManus 2000; Duncan and Hoffman 1985; Holden and Smock 1991). It has been found that for women, re-partnering is a more effective way to increase their economic well-being than expanding their employment activities (Jansen et al. 2009). Other studies have shown that repartnering has a smaller impact on women's economic well-being (McKeever and Wolfinger 2001; Ozawa and Yoon 2002). Unfortunately, there is no possibility to control for re-partnering in this study.

Shared parenting arrangements and child alimony can also mitigate economic consequences of divorce and separation. Currently in Sweden, 35\% of children with separated parents are in shared physical custody arrangements (SCB 2014). This share is considerably higher than it is in many other countries (Wadsby et al. 2014). 
When Swedish mothers instead collect child alimony, they often only receive the minimum level of $1250 \mathrm{SEK}^{1}$ per month, regardless of the father's income.

In addition to alimony payments, various forms of governmental support can mitigate the economic consequences of separation. Single parents may receive targeted cash benefits or more general types of support. The most common form of state support in Sweden is institutional childcare, which ensures that parents have access to the labour market. This type of support has been shown to benefit parents more than targeted income-related benefits (Bradshaw and Finch 2002; Maldonado and Nieuwenhuis 2015; Uunk 2004).

\section{Hypotheses}

In this study, changes in parents' earnings following the birth of their first child are analysed by comparing couples who separated with couples who stayed together for at least 8 years. From earlier research, we know that parents, and especially mothers, tend to suffer economically following a separation. To deal with the negative economic consequences of a separation, parents may seek to increase their labour earnings by, for example, moving to a better-paying job, increasing their working hours, or shortening their parental leave period. If parents who separate invest more in paid work in order to increase their earnings, it is likely that their human capital will also increase relative to that of coupled parents. If this is the case, it may be assumed that compared to coupled parents, separated parents experience more earnings growth, not just immediately after the separation, but over the long term.

If parents want to increase their labour earnings by increasing their working hours, their ability to do so depends on how much they were working before the separation. Having a child affects the working hours of parents in a highly gendered way, with men spending more time than women in paid work. Thus, men might have less room than women to improve their labour market earnings. However, having substantial childcare obligations could prevent women from expanding their paid work activities in order to increase their earnings. Hence, it is possible that separation has only small effects on the earnings trajectories of both mothers and fathers.

The economic impact of separation may differ depending on when the separation took place. As the mother often takes the initial period of parental leave, leaving the father to take parental leave later in the child's life (Eriksson 2018), women who separate in the year immediately after giving birth may face greater difficulties in adjusting their labour earnings in response to the separation than women who separate when their child is older. As fathers generally use considerably less parental leave than mothers, the timing of the separation might be less relevant for men than it is for women.

As individuals have different economic positions before they become parents, their options for adjusting their earnings in response to a separation are also likely

\footnotetext{
${ }^{1}$ This is the same amount that the government pays to parents with sole custody of the children when the other parent refuses to provide economic support (Statistics Sweden 2014).
} 
to differ. Parents with high labour earnings pre-birth may have been working longer hours, and might therefore have little room to further increase their hours postseparation. At the same time, however, parents with high pre-birth labour earnings may be in a better position than their counterparts with lower earnings to reduce their working hours. They might also have better chances of moving to a more parent-friendly job, or of trading higher earnings for more flexibility in order to improve their work-family balance post-separation. Yet parents who use this strategy risk having lower earnings growth in the long term due to human capital depreciation. Conversely, parents with low pre-birth labour earnings may have been in part-time work, and might thus have room for upward adjustments in earnings after a separation. Low-earning parents are also likely to need to increase their work earnings, as separation can be costly. Parents who pursue this strategy have lower chances of suffering from human capital depreciation, and higher chances of experiencing positive earnings growth in the long run. However, as having low labour earnings pre-birth is also associated with poorer job mobility and socio-economic circumstances, the ability of these parents to improve their labour earnings might be limited, leaving them especially vulnerable to the negative economic consequences of parental separation.

\section{Data, Variables, and Method}

\section{Method}

Earlier research on post-separation changes in earnings trajectories has not always compared women and men who separated with couples who stayed together. However, a study that focuses only on changes in earnings among those who separated risks overstating earnings losses. Hence, it is important to compare mothers and fathers who did and did not separate (Bayaz-Ozturk et al. 2018); especially given that couples who remain together also experience earnings changes in relation to childbirth. To estimate the earnings trajectories of parents in relation to their entry into parenthood and to the event of separation, and to identify possible differences between women and men who did and did not separate, I rely on fixed-effects models. Fixed-effects models control not only for observable variables, but for unobservable variables that are stable over time (Allison 2009). Nonetheless, time-varying unobservable differences between intact couples and separated couples can still result in selection effects.

The outcome variable is annual pre-tax earnings in SEK, not including workrelated transfers like parental leave benefits. While the transformation of earnings to a logged scale is often used, I do not use it here because my interest in this study lies in investigating within-person changes from 2 years before the birth, rather than in assessing proportionality between groups. The analysis is done separately for women and men in different labour earnings quartiles (see below). I estimate how women's and men's predicted earnings trajectories change across subgroups of 
couples who stayed together and couples who separated one, three, and 5 years after the first birth by modelling two-way interactions between time to/from birth and subgroups. The model can be summarised by the following equation:

$$
Y_{i t}=\sum_{s=-2}^{s=8} \eta_{s} D_{i} S_{i}+\gamma \boldsymbol{X}_{i t}+\alpha_{i}+\mu_{i t}
$$

where Y measures labour earnings for individual $i$ in year $t, D$ is a set of $s=11$ dummies for each year two before and up to eight after the first birth (reference is 2 years before the birth), and $S$ represents dummies for subgroups of women and men who stayed together and women and men who separated. The $\mathrm{X}$ is a vector of controls that vary across individuals and years. $\alpha_{i}$ is a couple-level fixed effect, and $\mu_{i t}$ is the error term. The control vectors consist of the time-varying events of having a second child and getting married, as well as the individual's own level of education, the other parent's level of education, and the other parent's annual labour earnings. Ideally, I would also control for re-partnering and hours worked, but the data used here do not allow me to do so.

\section{Data}

Having access to information on the total population from Swedish administrative registers allows me to perform a fine-grained analysis in which potential subgroup variation in earnings trajectories among first-time parents following separation is explored. I follow women and men who became parents for the first time between 2002 and 2004 using a panel dataset in which earnings trajectories are analysed separately in different earnings quartiles. The study population is restricted to women and men who had positive earnings 2 years before the birth, and who did not earn more than one million SEK during a given year (based on 2012 values). This restriction led to $7 \%$ of the original sample of couples being dropped in the analysis of women, and $10 \%$ being dropped in the analysis of men. The majority of the excluded cases were due to women or men lacking labour income 2 years before birth. Censoring was carried out if a parent emigrated or died during the observation window or before the union dissolution. In the study, 67,429 women and 70,330 men are followed from 2 years before the first birth. Due to censoring, around $2 \%$ of these women and men cannot be followed for a full 8 years after the first birth.

\section{Independent Variables}

To explore subgroup variation in earnings adjustments among women and men, the population is divided into earnings quartiles based on their labour earnings 2 years before the first birth. Table 3.1 reports the numbers of women and men who stayed together compared to the numbers who separated within 8 years of the first birth. 
Table 3.1a Number of women in labour earnings quartiles 2 years before the first birth

\begin{tabular}{l|l|l|l|l|l}
\hline & & \multicolumn{5}{|l}{ of which separated } \\
\cline { 3 - 6 } & Coupled & $\begin{array}{l}\text { Separation within } \\
8 \text { years after birth }\end{array}$ & $\begin{array}{l}\text { Separation when } \\
\text { child was age } \\
\text { one }\end{array}$ & $\begin{array}{l}\text { Separation when } \\
\text { child was age } \\
\text { three }\end{array}$ & $\begin{array}{l}\text { Separation when } \\
\text { child was age } \\
\text { five }\end{array}$ \\
\hline $\begin{array}{l}1 \text { st } \\
\text { quartile }\end{array}$ & 14,300 & 4499 & $44 \%$ & $39 \%$ & $35 \%$ \\
\hline $\begin{array}{l}\text { 2nd } \\
\text { quartile }\end{array}$ & 15,584 & 3208 & $24 \%$ & $27 \%$ & $27 \%$ \\
\hline $\begin{array}{l}\text { 3rd } \\
\text { quartile }\end{array}$ & 16,307 & 2481 & $18 \%$ & $20 \%$ & $20 \%$ \\
\hline $\begin{array}{l}\text { 4th } \\
\text { quartile }\end{array}$ & 16,704 & 2082 & $15 \%$ & $14 \%$ & $18 \%$ \\
\hline Total & 62,895 & 12,270 & 1369 & 1552 & 1613 \\
\hline
\end{tabular}

Table 3.1b Number of men in labour earnings quartiles 2 years before the first birth

\begin{tabular}{l|l|l|l|l|l}
\hline & & & \multicolumn{5}{|l}{ of which separated } & $\begin{array}{l}\text { Separation when } \\
\text { child was age } \\
\text { one }\end{array}$ & $\begin{array}{l}\text { Separation when } \\
\text { child was age } \\
\text { three }\end{array}$ & $\begin{array}{l}\text { Separation when } \\
\text { child was age } \\
\text { five }\end{array}$ \\
\hline $\begin{array}{l}\text { 1st } \\
\text { quartile }\end{array}$ & 14,613 & 5155 & $45 \%$ & $40 \%$ & $35 \%$ \\
\hline $\begin{array}{l}\text { 2nd } \\
\text { quartile }\end{array}$ & 16,088 & 3671 & $24 \%$ & $26 \%$ & $28 \%$ \\
\hline $\begin{array}{l}\text { 3rd } \\
\text { quartile }\end{array}$ & 16,822 & 2949 & $17 \%$ & $20 \%$ & $19 \%$ \\
\hline $\begin{array}{l}\text { 4th } \\
\text { quartile }\end{array}$ & 17,506 & 2250 & $14 \%$ & $14 \%$ & $17 \%$ \\
\hline Total & 65,029 & 14,025 & 1632 & 1844 & 1825 \\
\hline
\end{tabular}

The findings displayed in the table show that separation is associated with lower earnings, as nearly $40 \%$ of the women and men who separated, compared to just over $20 \%$ of the women and men who stayed together, are in the lowest earnings quartile. The results also indicate that the women and men who separated 1 year after the first birth are overrepresented in the lowest earnings quartile compared to the women and men who separated later (see shares in Tables 3.1a and b).

Education is measured as the educational attainment for both the index person and the other parent. This indicator is allowed to vary over years, as it is common for women and men in Sweden to increase their levels of education later in life, even after becoming parents (Thalberg 2013). Like the dependent variable, the labour earnings of the other parent are measured annually as pre-tax earnings in SEK, not including work-related transfers like parental leave benefits. The event of a second birth or of a marriage is controlled for yearly as a binary variable. 


\section{Results}

\section{Descriptive Results}

Tables 3.2a and b report the average labour earnings 2 years before the first birth among women and men. We can see that men tended to have higher earnings than women before the birth. This observation is partly attributable to men being somewhat older than their partners when they become parents, but it is also due to gender differences on the labour market. The earnings differences 2 years before the first birth are small between the women and men who stayed coupled for at least 8 years and the women and men who separated.

The general earnings trajectories are illustrated in Fig. 3.1, and show that both women's and men's earnings decreased following childbirth. However, women's earnings decreased more because they generally took a longer parental leave. A second earnings dip is also visible among women 3 years after the first birth. This is due to the birth of a second child. At 8 years after the first birth, women's earnings had returned to their pre-birth earnings level, while men's earnings had surpassed that level. This is found to be the case for all parents, regardless of when they separated (not shown in Fig. 3.1).

\section{Regression Results}

The results from the fixed-effects models are presented in terms of average predicted probabilities (average marginal effects). Figure 3.2 visualises women's earnings trajectories from 2 years before the first birth to 8 years after. Due to the width

Table 3.2a Average labour earnings 2 years before the first birth in thousands of SEK, women

\begin{tabular}{l|l|l|l|l}
\hline & Coupled & $\begin{array}{l}\text { Separation when } \\
\text { child was age one }\end{array}$ & $\begin{array}{l}\text { Separation when } \\
\text { child was age three }\end{array}$ & $\begin{array}{l}\text { Separation when } \\
\text { child was age five }\end{array}$ \\
\hline 1st quartile & 143 & 139 & 140 & 141 \\
\hline 2nd quartile & 218 & 216 & 216 & 215 \\
\hline 3rd quartile & 265 & 264 & 265 & 264 \\
\hline 4th quartile & 378 & 382 & 372 & 369 \\
\hline
\end{tabular}

Table 3.2b Average labour earnings 2 years before the first birth in thousands of SEK, men

\begin{tabular}{l|l|l|l|l}
\hline & Coupled & $\begin{array}{l}\text { Separation when } \\
\text { child was age one }\end{array}$ & $\begin{array}{l}\text { Separation when } \\
\text { child was age three }\end{array}$ & $\begin{array}{l}\text { Separation when } \\
\text { child was age five }\end{array}$ \\
\hline 1st quartile & 177 & 168 & 172 & 173 \\
\hline 2nd quartile & 264 & 262 & 263 & 263 \\
\hline 3rd quartile & 321 & 320 & 318 & 320 \\
\hline 4th quartile & 457 & 461 & 443 & 462 \\
\hline
\end{tabular}



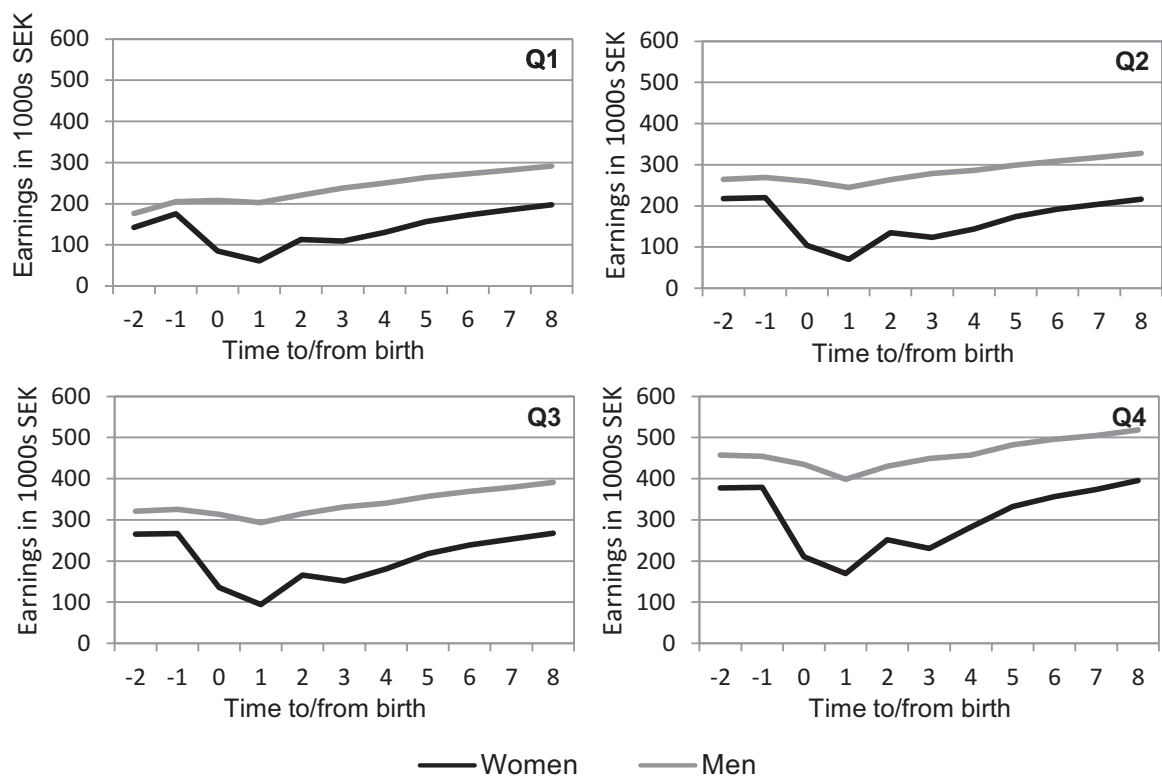

Fig. 3.1 Average labour earnings by time to/from the first birth in earnings quartiles 2 years before the first birth

of the scale, the differences between women who separated and women who stayed coupled can be hard to discern in the figure. Therefore, Table 3.3 also shows the differences in percentage points between separated and coupled women. The full set of marginal effects, including confidence intervals, are found in Tables 3.5-3.12 in the appendix.

Women who separated, with the exception of those in the two highest earnings quartiles, are shown to have more positive earnings trajectories in the year of separation than women who stayed coupled. This finding indicates that these women increased their labour supply, and thus increased their labour earnings after separating. However, these differences are small and often statistically insignificant. Hence, it appears that the development of earnings among women prior to separation and a few years after separation was similar to the development among women who stayed coupled. But by 8 years after the first birth, the earnings trajectories of separated and coupled women had diverged, leaving separated women with poorer earnings trajectories. This lagged effect of separation is most evident among women who separated one or 3 years after the first birth. However, it is possible that the gap between coupled women and women who separated 5 years after the first birth will increase as time goes by. The largest discrepancies in changes in earnings are found between coupled women and separated women in the lowest earnings quartile. Between these women, a gap of up to 40 percentage points in earnings growth can be seen 8 years after the first birth. 

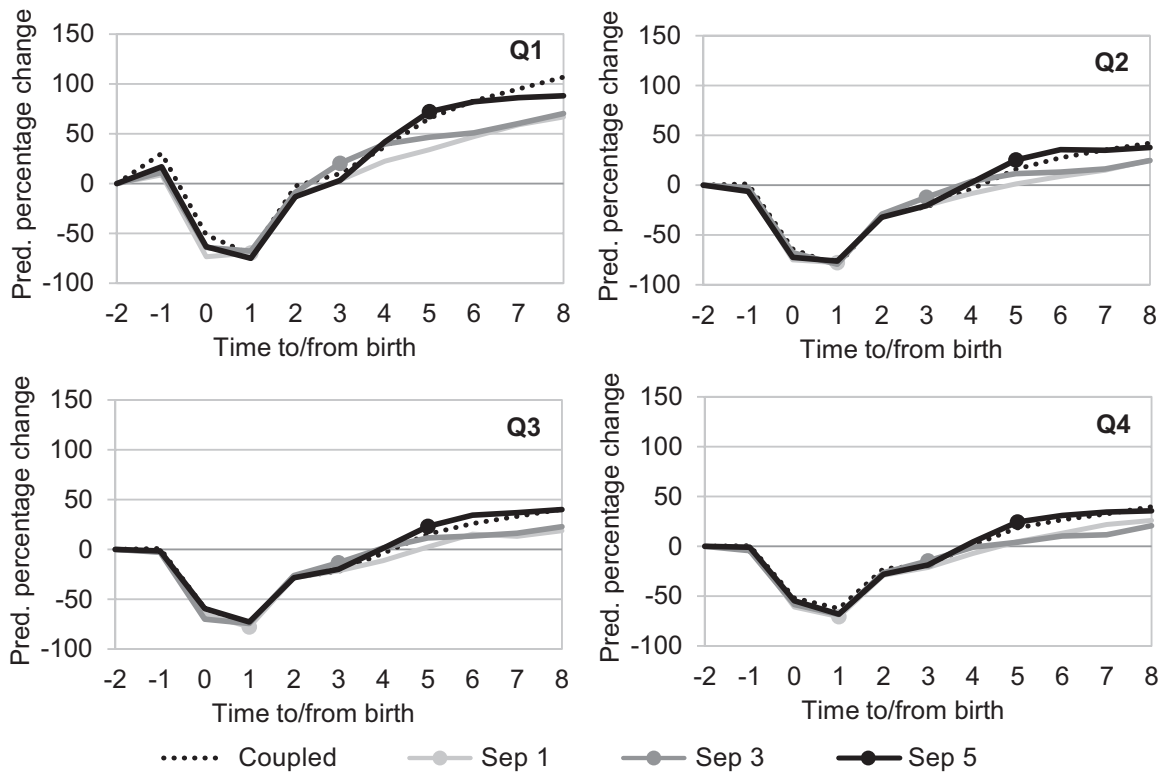

Fig. 3.2 Predicted percentage change from 2 years before the first birth among women by subgroups and earnings quartiles

Notes: Results from fixed-effects model with annual earnings as a dependent variable. Control variables are: annual labour earnings of the other parent, own educational level and educational level of the other parent, event of marriage, and event of the second birth

Table 3.3 Percentage point distance from coupled women's predicted changes in labour earnings at the year of separation and at 8 years after the first birth

\begin{tabular}{l|l|l|l|l|l|l}
\hline & \multicolumn{3}{|l|}{ Year of separation } & \multicolumn{2}{l}{ Eight years after birth } \\
\cline { 2 - 7 } & $\begin{array}{l}\text { Separation } \\
\text { when child } \\
\text { was age one }\end{array}$ & $\begin{array}{l}\text { Separation } \\
\text { when child } \\
\text { was age } \\
\text { three }\end{array}$ & $\begin{array}{l}\text { Separation } \\
\text { when child } \\
\text { was age five }\end{array}$ & $\begin{array}{l}\text { Separation } \\
\text { when child } \\
\text { was age one }\end{array}$ & $\begin{array}{l}\text { Separation } \\
\text { when child } \\
\text { was age } \\
\text { three }\end{array}$ & $\begin{array}{l}\text { Separation } \\
\text { when child } \\
\text { was age five }\end{array}$ \\
\hline $\begin{array}{l}\text { 1st } \\
\text { quartile }\end{array}$ & 1 & 10 & 6 & -40 & -37 & -19 \\
\hline $\begin{array}{l}\text { 2nd } \\
\text { quartile }\end{array}$ & 3 & 10 & 9 & -17 & -18 & -4 \\
\hline $\begin{array}{l}\text { 3rd } \\
\text { quartile }\end{array}$ & -2 & 9 & 8 & -21 & -17 & 0 \\
\hline $\begin{array}{l}\text { 4th } \\
\text { quartile }\end{array}$ & -8 & 4 & 6 & -14 & -19 & -4 \\
\hline
\end{tabular}

Notes: see Fig. 3.2 

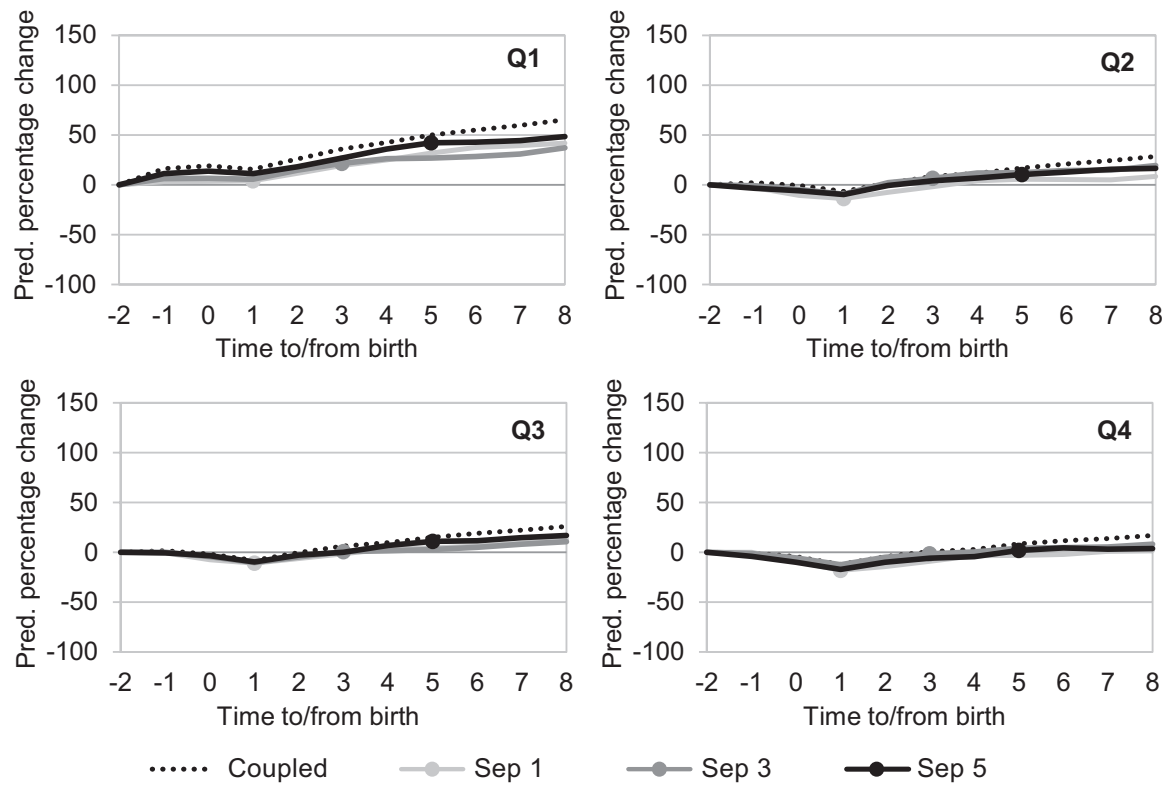

Fig. 3.3 Predicted percentage change from 2 years before the first birth among men by subgroups and earnings quartiles

Notes: Results from fixed-effects model with annual earnings as a dependent variable. Control variables are: annual labour earnings of the other parent, own educational level and educational level of the other parent, event of marriage, and event of second birth.

Figure 3.3 shows the predicted changes in earnings between men who separated and men who stayed coupled. As above, the differences in earnings changes between the study groups are also given in numbers in Table 3.4. Unlike among women, the results show that men who separated had poorer earnings growth directly after separating than men who stayed coupled. These poorer earnings developments intensified with time. Thus, like among women, we find a lagged separation effect on men's earnings trajectories 8 years after the first birth. The discrepancies in earnings growth between separated and coupled men observed at 8 years after the first birth were often close to the magnitude of the differences found among women in earnings quartiles two to four. The discrepancies between men are found to be largest in the lowest earnings quartile, but still considerably smaller than those detected among women in the lowest earnings quartile. However, earnings growth at 8 years after the first birth are shown to be lower among men who separated 5 years after the first birth than among men who stayed coupled, and this difference appears to be greater than it is among women. Moreover, earnings developments among men in the lowest earnings quartile stand out compared to those among men in the higher earnings quartiles, as coupled men displayed stronger earnings growth than separated men even before they separated. This result could be due to selection effects that the statistical methods cannot account for. 
Table 3.4 Percentage point distance from coupled men's predicted changes in work income at year of separation and at 8 years after birth

\begin{tabular}{l|l|l|l|l|l|l}
\hline & \multicolumn{3}{|l|}{ Year of separation } & \multicolumn{3}{l}{ Eight years after birth } \\
\cline { 2 - 7 } & $\begin{array}{l}\text { Separation } \\
\text { when child } \\
\text { was age one }\end{array}$ & $\begin{array}{l}\text { Separation } \\
\text { when child } \\
\text { was age } \\
\text { three }\end{array}$ & $\begin{array}{l}\text { Separation } \\
\text { when child } \\
\text { was age five }\end{array}$ & $\begin{array}{l}\text { Separation } \\
\text { when child } \\
\text { was age one }\end{array}$ & $\begin{array}{l}\text { Separation } \\
\text { when child } \\
\text { was age } \\
\text { three }\end{array}$ & $\begin{array}{l}\text { Separation } \\
\text { when child } \\
\text { was age five }\end{array}$ \\
\hline $\begin{array}{l}1 \text { st } \\
\text { quartile }\end{array}$ & -12 & -14 & -8 & -23 & -28 & -17 \\
\hline $\begin{array}{l}\text { 2nd } \\
\text { quartile }\end{array}$ & -7 & -2 & -7 & -20 & -9 & -12 \\
\hline $\begin{array}{l}\text { 3rd } \\
\text { quartile }\end{array}$ & -3 & -6 & -4 & -13 & -15 & -9 \\
\hline $\begin{array}{l}\text { 4th } \\
\text { quartile }\end{array}$ & -6 & -2 & -7 & -15 & -9 & -13 \\
\hline
\end{tabular}

Notes: see Fig. 3.3

\section{Discussion}

Prior research has shown that divorce and separation have negative economic consequences for both women and men. Typically, the disposable incomes of the expartners decline because they move into separate households and no longer benefit from the economies of scale that exist when resources are pooled in one household unit. Moreover, women often experience a rapid decrease in their equivalent household income, both because they continue to reside with their children, and because they may not have worked full-time prior to the union dissolution. Thus, in most cases, women and men need to increase their labour supply and their own labour earnings following a separation. A positive side effect of this pressure is that the ex-partners' human capital accumulation should increase as well, which should result in separated parents having better earnings trajectories than coupled mothers and fathers. However, the findings from this study do not support this assumption. Instead, a lagged separation effect is detected, whereby separated parents were on a lower earnings trajectory than coupled parents 8 years after the separation. A gendered effect is found to exist, as the gaps between the earnings developments of separated and coupled women were considerably larger than they were among men. It appears that the timing of separation had little effect on the results, with the possible exception for those parents who separated 5 years after the first birth. Separated women and men in the lowest pre-birth earnings quartile suffered from the poorest earnings growth compared to coupled parents.

The finding that the earnings adjustments directly following separation were small is in line with cross-national findings on changes in household income after separation. Andreß et al. (2006) found that the negative economic consequences of separation were smaller and more gender-equal in Sweden than they were in Belgium, Germany, Great Britain, and Italy. They attributed this pattern to Sweden's high employment rate among mothers, which they argued acts as a safeguard against 
economic difficulties. As most women and men in Sweden tend to be in full time paid work, their opportunities to increase their working hours in order to improve their earnings are small. Even when on parental leave, their earnings are secured. Thus, the extent to which women and men in Sweden need to improve their economic situations after separating might be lower than it is elsewhere. This could also be a reason why in this study the timing of separation is shown to have a rather small effect on earnings developments.

However, even though the negative consequences of separation appear to be more modest in Sweden than in other countries, Andreß et al. (2006) also found that women and men have to deal with more long-run negative consequences in Sweden than they do in other countries. This observation matches this study's finding of a lagged separation effect on labour earnings. This result raises the question of what the causes of such a lagged separation effect might be. It is possible that single parents reduce their labour supply in the long run. As time elapses, parents might feel the need to decrease their work hours in order to balance their total workload at the expense of higher earnings. An argument that speaks against this interpretation is that over time, children are becoming increasingly independent. The chances of a new partner joining the family also rise, balancing out the increased workload the parent faces while single. This should make room for parents who are separated to once again focus on paid work to a similar degree as coupled parents, which should, in turn, result in improved earnings trajectories. As no evidence of such a pattern is found in this study, other factors might be at play. It is possible that employer discrimination against single parents has an impact. Earlier research has shown that both women and men are punished with wage losses (Aisenbrey et al. 2009; Albrecht et al. 2015; Evertsson 2016; Gangl and Ziefle 2009), possibly due to reductions in human capital accumulation when they become parents (Becker 1993; Mincer and Polacheck 1974). Although these wage penalties are small in Nordic countries (Sigle-Rushton and Waldfogel 2007), they may have a greater impact on separated parents if employers perceive them as having more difficulties committing themselves to paid work than parents in intact couples. An important task for future research is to isolate the effects that stem from employer behaviour from the effects that are related to lone parents' deliberate choices to reduce their labour market engagement.

The assumption that parents with differing initial resources tackle separation differently is confirmed to some extent. The results show that women in the highest earnings quartile who separated 1 year after the first birth saw a decrease in their earnings (compared to coupled women in the same earnings bracket). This finding could be due to these women taking more unpaid parental leave days than others (see Duvander and Korsell in this volume). The strategy of trading earnings for family time is most often used by those with economic flexibility to do so (Alsarve et al. 2017). It appears, however, that the use of this strategy did not result in poorer earnings growth in the long term for the women in this group, as theories on human capital depreciation suggest. Instead, the lagged separation effect is found to be strongest among parents with the lowest pre-birth labour earnings. This finding indicates that these parents are especially vulnerable to the economic consequences of separation. While the belief that employment is the best strategy to shield parents from poverty 
is strongly anchored in Swedish policy-making, it may be difficult for some groups of low-income parents in this country to increase their earnings. As labour markets have become more unequal and employment more precarious, the economic wellbeing of single parents is under threat. In line with Nieuwenhuis and Maldonado (2018), it can be argued that social benefits, social assistance, and child support payments are important instruments for improving the economic well-being of single parents.

Acknowledgments This work was supported by the Swedish Research Council for Health, Working Life and Welfare [2015-01139] and the Swedish Research Council [2015-013191].

\section{Appendix (Tables 3.5, 3.6, 3.7, 3.8, 3.9, 3.10, 3.11 and 3.12)}

Table 3.5 Predicted marginal effect on labour earnings from 2 years before the first birth among women in earnings quartile 1 , by time to/from the first birth

\begin{tabular}{|c|c|c|c|c|c|c|c|c|}
\hline & Coupled & & Sep. 1 & & Sep. 3 & & Sep. 5 & \\
\hline-2 & 110,353 & \pm 1367 & 110,353 & \pm 1367 & 110,353 & \pm 1367 & 110,353 & \pm 1367 \\
\hline-1 & 143,791 & \pm 1435 & 120,047 & \pm 8220 & 122,559 & \pm 8142 & 128,731 & \pm 8408 \\
\hline 0 & 53,308 & \pm 1419 & 29,410 & \pm 8207 & 39,492 & \pm 8130 & 40,314 & \pm 8405 \\
\hline 1 & 32,039 & \pm 1380 & 33,467 & \pm 8202 & 35,581 & \pm 8120 & 27,469 & \pm 8397 \\
\hline 2 & 107,686 & \pm 1261 & 97,238 & \pm 8200 & 100,725 & \pm 8108 & 95,906 & \pm 8375 \\
\hline 3 & 121,328 & \pm 1281 & 114,164 & \pm 8195 & 132,827 & \pm 8106 & 113,625 & \pm 8372 \\
\hline 4 & 151,079 & \pm 1335 & 135,217 & \pm 8195 & 153,981 & \pm 8115 & 156,500 & \pm 8374 \\
\hline 5 & 182,688 & \pm 1373 & 147,915 & \pm 8216 & 161,647 & \pm 8126 & 189,859 & \pm 8377 \\
\hline 6 & 201,895 & \pm 1401 & 162,373 & \pm 8225 & 166,301 & \pm 8141 & 200,993 & \pm 8385 \\
\hline 7 & 215,192 & \pm 1421 & 175,592 & \pm 8236 & 176,830 & \pm 8144 & 205,482 & \pm 8396 \\
\hline 8 & 228,284 & \pm 1442 & 184,171 & \pm 8260 & 187,993 & \pm 8155 & 207,629 & \pm 8401 \\
\hline
\end{tabular}

Table 3.6 Predicted marginal effect on labour earnings from 2 years before the first birth among women in earnings quartile 2 , by time to/from the first birth

\begin{tabular}{l|r|l|r|l|r|r|r|l}
\hline & \multicolumn{3}{|l}{ Coupled } & \multicolumn{1}{l}{ Sep. 1 } & \multicolumn{3}{l|}{ Sep. 3 } & \multicolumn{3}{l}{ Sep. 5 } \\
\hline-2 & 176,894 & \pm 1244 & 176,894 & \pm 1244 & 176,894 & \pm 1244 & 176,894 & \pm 1244 \\
\hline-1 & 178,867 & \pm 1275 & 170,275 & $\pm 10,409$ & 172,397 & \pm 9068 & 165,875 & \pm 8903 \\
\hline 0 & 63,561 & \pm 1260 & 43,954 & $\pm 10,404$ & 56,685 & \pm 9066 & 48,479 & \pm 8896 \\
\hline 1 & 33,390 & \pm 1227 & 39,047 & $\pm 10,402$ & 36,141 & \pm 9062 & 41,822 & \pm 8889 \\
\hline 2 & 125,580 & \pm 1108 & 121,273 & $\pm 10,431$ & 125,286 & \pm 9052 & 119,810 & \pm 8876 \\
\hline 3 & 137,971 & \pm 1124 & 140,872 & $\pm 10,467$ & 155,212 & \pm 9053 & 140,333 & \pm 8876 \\
\hline 4 & 169,727 & \pm 1173 & 162,104 & $\pm 10,466$ & 183,281 & \pm 9075 & 181,364 & \pm 8877 \\
\hline 5 & 204,954 & \pm 1208 & 178,862 & $\pm 10,466$ & 197,404 & \pm 9098 & 221,336 & \pm 8879 \\
\hline 6 & 225,378 & \pm 1233 & 192,442 & $\pm 10,467$ & 199,947 & \pm 9110 & 239,992 & \pm 8885 \\
\hline 7 & 239,391 & \pm 1251 & 203,392 & $\pm 10,487$ & 205,400 & \pm 9137 & 238,789 & \pm 8891 \\
\hline 8 & 251,535 & \pm 1269 & 221,234 & $\pm 10,498$ & 220,158 & \pm 9144 & 243,618 & \pm 8903 \\
\hline
\end{tabular}


3 Earnings Trajectories Following Parental Separation Among First-Time Parents...

Table 3.7 Predicted marginal effect on labour earnings from 2 years before the first birth among women in earnings quartile 3 , by time to/from the first birth

\begin{tabular}{|c|c|c|c|c|c|c|c|c|}
\hline & Coupled & & Sep. 1 & & Sep. 3 & & Sep. 5 & \\
\hline-2 & 218,437 & 1400 & 218,437 & 1400 & 218,437 & 1400 & 218,437 & 1400 \\
\hline-1 & 220,089 & 1400 & 211,909 & 13,520 & 211,934 & 11,817 & 214,870 & 11,815 \\
\hline 0 & 89,526 & 1382 & 76,649 & 13,519 & 65,411 & 11,814 & 88,338 & 11,812 \\
\hline 1 & 53,633 & 1342 & 48,182 & 13,518 & 55,780 & 11,810 & 58,937 & 11,807 \\
\hline 2 & 157,494 & 1198 & 156,123 & 13,510 & 161,198 & 11,789 & 155,939 & 11,791 \\
\hline 3 & 169,758 & 1228 & 171,224 & 13,557 & 188,713 & 11,790 & 174,349 & 11,783 \\
\hline 4 & 210,113 & 1283 & 193,873 & & 221,573 & 11,817 & 221,262 & 11,777 \\
\hline 5 & 251,844 & 1316 & 223,629 & 13,654 & 243,641 & 11,816 & 268,676 & 11,780 \\
\hline 6 & 275,045 & 1338 & 251,395 & 13,706 & 247,786 & 11,835 & 293,229 & 11,790 \\
\hline 7 & 290,825 & 1354 & 246,767 & 13,720 & 253,774 & 11,845 & 299,049 & 11,812 \\
\hline . & 306,114 & 1369 & 259,253 & 13,721 & 268,212 & 11,866 & 305,962 & 11,810 \\
\hline
\end{tabular}

Table 3.8 Predicted marginal effect on labour earnings from 2 years before the first birth among women in earnings quartile 4 , by time to/from the first birth

\begin{tabular}{|c|c|c|c|c|c|c|c|c|}
\hline & Coupled & & Sep. 1 & & Sep. 3 & & Sep. 5 & \\
\hline-2 & 317,109 & 2052 & 317,109 & 2052 & 317,109 & 2052 & 317,109 & 2052 \\
\hline-1 & 318,813 & 2023 & 313,845 & 21,386 & 303,211 & 20,893 & 314,164 & 17,668 \\
\hline 0 & 152,012 & 1996 & 123,569 & 21,385 & 131,328 & 20,892 & 143,645 & 17,661 \\
\hline 1 & 119,176 & 1935 & 93,309 & 21,382 & 100,368 & 20,843 & 100,468 & 17,653 \\
\hline 2 & 245,105 & 1713 & 224,883 & 21,401 & 232,360 & 20,826 & 227,314 & 17,633 \\
\hline 3 & 256,269 & 1775 & 249,313 & 21,406 & 269,896 & 20,827 & 257,538 & 17,637 \\
\hline 4 & 321,291 & 1854 & 293,852 & 21,436 & 313,802 & 20,833 & 331,022 & 17,639 \\
\hline 5 & 375,349 & 1894 & 331,550 & 21,436 & 329,272 & 20,861 & 394,474 & 17,645 \\
\hline 6 & 401,531 & 1919 & 358,759 & 21,437 & 349,369 & 20,944 & 414,676 & 17,661 \\
\hline 7 & 420,116 & 1937 & 386,408 & 21,499 & 353,877 & 20,932 & 425,679 & 17,678 \\
\hline 8 & 443,067 & 1954 & 399,021 & 21,498 & 382,451 & 20,959 & 429,356 & 17,679 \\
\hline
\end{tabular}

Table 3.9 Predicted marginal effect on labour earnings from 2 years before the first birth among men in earnings quartile 1 , by time to/from the first birth

\begin{tabular}{l|l|l|l|l|l|l|l|l}
\hline & \multicolumn{3}{|l|}{ Coupled } & \multicolumn{2}{l}{ Sep. 1 } & \multicolumn{3}{l}{ Sep. 3 } \\
\hline-2 & 178,136 & \pm 1491 & 178,136 & \pm 1491 & 178,136 & \pm 1491 & 178,136 & \pm 1491 \\
\hline-1 & 206,797 & \pm 1583 & 183,360 & \pm 8390 & 189,147 & \pm 8255 & 198,241 & \pm 8811 \\
\hline 0 & 212,103 & \pm 1629 & 184,131 & \pm 8375 & 189,832 & \pm 8253 & 202,260 & \pm 8822 \\
\hline 1 & 206,012 & \pm 1620 & 185,010 & \pm 8369 & 187,991 & \pm 8244 & 197,770 & \pm 8815 \\
\hline 2 & 224,095 & \pm 1415 & 198,808 & \pm 8362 & 203,965 & \pm 8221 & 210,156 & \pm 8780 \\
\hline 3 & 241,757 & \pm 1434 & 212,433 & \pm 8356 & 216,424 & \pm 8219 & 226,142 & \pm 8778 \\
\hline 4 & 253,506 & \pm 1486 & 222,698 & \pm 8373 & 224,891 & \pm 8232 & 241,873 & \pm 8778 \\
\hline 5 & 267,011 & \pm 1539 & 234,757 & \pm 8381 & 225,768 & \pm 8242 & 253,059 & \pm 8786 \\
\hline 6 & 276,143 & \pm 1583 & 244,805 & \pm 8389 & 228,899 & \pm 8253 & 254,391 & \pm 8797 \\
\hline 7 & 284,513 & \pm 1617 & 248,145 & \pm 8405 & 233,115 & \pm 8268 & 256,991 & \pm 8811 \\
\hline 8 & 294,145 & \pm 1650 & 252,649 & \pm 8418 & 244,278 & \pm 8284 & 264,223 & \pm 8815 \\
\hline
\end{tabular}


Table 3.10 Predicted marginal effect on labour earnings from 2 years before the first birth among men in earnings quartile 2, by time to/from the first birth

\begin{tabular}{l|l|l|l|l|l|l|l|l}
\hline & \multicolumn{3}{l}{ Coupled } & \multicolumn{3}{l|}{ Sep. 1 } & \multicolumn{3}{l}{ Sep. 3 } & \multicolumn{2}{l}{ Sep. 5 } \\
\hline-2 & 259,956 & \pm 1237 & 259,956 & \pm 1237 & 259,956 & \pm 1237 & 259,956 & \pm 1237 \\
\hline-1 & 265,662 & \pm 1275 & 252,377 & \pm 9761 & 256,988 & \pm 8644 & 250,494 & \pm 8385 \\
\hline 0 & 257,868 & \pm 1332 & 232,455 & \pm 9768 & 247,685 & \pm 8647 & 244,542 & \pm 8385 \\
\hline 1 & 242,912 & \pm 1333 & 224,422 & \pm 9766 & 235,123 & \pm 8642 & 234,341 & \pm 8373 \\
\hline 2 & 263,803 & \pm 1127 & 239,976 & \pm 9757 & 265,149 & \pm 8616 & 258,390 & \pm 8349 \\
\hline 3 & 281,859 & \pm 1138 & 255,192 & \pm 9765 & 276,603 & \pm 8618 & 270,518 & \pm 8345 \\
\hline 4 & 289,763 & \pm 1183 & 270,428 & \pm 9772 & 290,788 & \pm 8624 & 277,707 & \pm 8348 \\
\hline 5 & 303,788 & \pm 1229 & 274,638 & \pm 9794 & 291,687 & \pm 8645 & 286,360 & \pm 8354 \\
\hline 6 & 313,847 & \pm 1266 & 273,519 & \pm 9811 & 297,008 & \pm 8653 & 293,031 & \pm 8376 \\
\hline 7 & 322,965 & \pm 1294 & 272,997 & \pm 9823 & 297,648 & \pm 8655 & 300,745 & \pm 8379 \\
\hline 8 & 333,414 & \pm 1322 & 281,807 & \pm 9833 & 309,860 & \pm 8659 & 302,633 & \pm 8388 \\
\hline
\end{tabular}

Table 3.11 Predicted marginal effect on labour earnings from 2 years before the first birth among men in earnings quartile 3 , by time to/from the first birth

\begin{tabular}{l|l|l|l|l|l|l|l|l}
\hline & Coupled & \multicolumn{3}{l}{ Sep. 1 } & \multicolumn{3}{l|}{ Sep. 3 } & \multicolumn{3}{l}{ Sep. 5 } \\
\hline-2 & 315,239 & \pm 1358 & 315,239 & \pm 1358 & 315,239 & \pm 1358 & 315,239 & $\pm 13,580$ \\
\hline-1 & 320,041 & \pm 1368 & 312,681 & $\pm 12,578$ & 315,175 & $\pm 11,065$ & 312,700 & $\pm 11,090$ \\
\hline 0 & 309,163 & \pm 1428 & 291,200 & $\pm 12,573$ & 301,610 & $\pm 11,057$ & 304,030 & $\pm 11,097$ \\
\hline 1 & 289,400 & \pm 1433 & 280,214 & $\pm 12,552$ & 282,646 & $\pm 11,046$ & 284,972 & $\pm 11,093$ \\
\hline 2 & 314,409 & \pm 1193 & 295,564 & $\pm 12,584$ & 300,157 & $\pm 11,027$ & 306,172 & $\pm 11,070$ \\
\hline 3 & 334,611 & \pm 1210 & 310,563 & $\pm 12,594$ & 316,940 & $\pm 11,020$ & 314,754 & $\pm 11,070$ \\
\hline 4 & 345,081 & \pm 1260 & 326,833 & $\pm 12,621$ & 319,917 & $\pm 11,035$ & 336,215 & $\pm 11,073$ \\
\hline 5 & 361,946 & \pm 1307 & 328,349 & $\pm 12,621$ & 323,483 & $\pm 11,037$ & 349,561 & $\pm 11,080$ \\
\hline 6 & 375,043 & \pm 1348 & 334,741 & $\pm 12,649$ & 331,156 & $\pm 11,031$ & 351,552 & $\pm 11,089$ \\
\hline 7 & 384,600 & \pm 1376 & 344,007 & $\pm 12,663$ & 340,810 & $\pm 11,049$ & 361,460 & $\pm 11,100$ \\
\hline 8 & 397,124 & \pm 1405 & 356,506 & $\pm 12,666$ & 348,610 & $\pm 11,076$ & 368,177 & $\pm 11,100$ \\
\hline
\end{tabular}

Table 3.12 Predicted marginal effect on labour earnings from 2 years before the first birth among men in earnings quartile 4 , by time to/from the first birth

\begin{tabular}{l|l|l|l|l|l|l|l|l}
\hline & \multicolumn{3}{|l}{ Coupled } & \multicolumn{3}{l}{ Sep. 1 } & \multicolumn{3}{l|}{ Sep. 3 } & \multicolumn{3}{l}{ Sep. 5 } \\
\hline-2 & 450,096 & \pm 1883 & 450,096 & $\pm 18,830$ & 450,096 & \pm 1883 & 450,096 & $\pm 18,830$ \\
\hline-1 & 447,523 & \pm 1862 & 449,187 & $\pm 18,964$ & 444,217 & $\pm 18,201$ & 431,135 & $\pm 16,616$ \\
\hline 0 & 429,525 & \pm 1918 & 409,080 & $\pm 18,953$ & 424,267 & $\pm 18,157$ & 404,226 & $\pm 16,610$ \\
\hline 1 & 394,625 & \pm 1914 & 368,411 & $\pm 18,953$ & 393,079 & $\pm 18,157$ & 372,149 & $\pm 16,609$ \\
\hline 2 & 430,255 & \pm 1607 & 385,110 & $\pm 18,957$ & 426,984 & $\pm 18,132$ & 405,129 & $\pm 16,564$ \\
\hline 3 & 452,691 & \pm 1651 & 408,401 & $\pm 19,051$ & 442,426 & $\pm 18,132$ & 423,204 & $\pm 16,554$ \\
\hline 4 & 462,265 & \pm 1716 & 434,737 & $\pm 19,048$ & 450,684 & $\pm 18,181$ & 429,901 & $\pm 16,544$ \\
\hline 5 & 487,682 & \pm 1776 & 435,958 & $\pm 19,074$ & 468,419 & $\pm 18,203$ & 458,209 & $\pm 16,552$ \\
\hline 6 & 501,709 & \pm 1819 & 439,876 & $\pm 19,077$ & 471,031 & $\pm 18,263$ & 470,144 & $\pm 16,569$ \\
\hline 7 & 511,708 & \pm 1852 & 453,599 & $\pm 19,102$ & 473,319 & $\pm 18,302$ & 463,457 & $\pm 16,572$ \\
\hline 8 & 525,738 & \pm 1890 & 458,882 & $\pm 19,129$ & 486,733 & $\pm 18,324$ & 467,187 & $\pm 16,573$ \\
\hline
\end{tabular}




\section{References}

Aisenbrey, S., Evertsson, M., \& Grunow, D. (2009). Is there a career penalty for mothers' time out? A comparison of Germany, Sweden and the United States. Social Forces, 88(2), 573-606. https://doi.org/10.1353/sof.0.0252.

Albrecht, J. M., Edin, P.-A., Sundström, M., \& Vroman, S. B. (1999). Career interruptions and subsequent earnings: A reexamination using Swedish data. The Journal of Human Resources, 34(2), 294-311. https://doi.org/10.2307/146347.

Albrecht, J., Thoursie, P., \& Vroman, S. (2015). Parental leave and the glass ceiling in Sweden (Working paper 2015: 14). Uppsala: IFAU, Institutet för arbetsmarknadspolitisk utvärdering.

Allison, P. D. (2009). Fixed effects regression models (Quantitative applications in the social sciences, Vol. 160). London: SAGE Publications.

Alsarve, J., Lundqvist, Å., \& Roman, C. (2017). Ensamma mammor: Dilemman, resurser, strategier. Malmö: Gleerups.

Andersson, G., \& Kolk, M. (2016). Trends in childbearing, marriage and divorce in Sweden: An update with data up to 2012. Finnish Yearbook of Population Research, 50(2015), 21-30.

Andreß, H. J., Borgloh, B., Bröckel, M., Giesselmann, M., \& Hummelsheim, D. (2006). The economic consequences of partnership dissolution: A comparative analysis of panel studies from Belgium, Germany, Great Britain, Italy, and Sweden. European Sociological Review, 22(5), 533-560. https://doi.org/10.1093/esr/jcl012.

Angelov, N., Johansson, P., \& Lindahl, E. (2016). Parenthood and the gender gap in pay. Journal of Labor Economics, 34(3), 545-579. https://doi.org/10.1086/684851.

Bayaz-Ozturk, G., Burkhauser, R. V., Couch, K. A., \& Hauser, R. (2018). The effects of union dissolution on the economic resources of men and women: A comparative analysis of Germany and the United States, 1985-2013. The Annals of the American Academy of Political and Social Science, 680(1), 235-258. https://doi.org/10.1177/0002716218793608.

Becker, G. S. (1993). Human capital: A theoretical and empirical analysis, with special reference to education. Chicago: University of Chicago Press.

Bradshaw, J., \& Finch, N. (2002). A comparison of child benefit packages in 22 countries (Research report no 174). Leeds: Department for Work and Pensions.

Budig, J. M., \& England, P. (2001). The wage penalty for motherhood. American Sociological Review, 66(2), 204-225. https://doi.org/10.2307/2657415.

Cooke, L. P. (2014). Gendered parenthood penalties and premiums across the earnings distribution in Australia, the United Kingdom, and the United States. European Sociological Review, 30(3), 360-372. https://doi.org/10.1093/esr/jcu044.

de Vaus, D., Gray, M., Qu, L., \& Stanton, D. (2017). The economic consequences of divorce in six OECD countries. Australian Social Policy Association, 52(2), 180-199. https://doi. org/10.1002/ajs4.13.

DiPrete, T. A., \& McManus, P. A. (2000). Family change, employment transitions, and the welfare state: Household income dynamics in the United States and Germany. American Sociological Review, 65(3), 343-370. https://doi.org/10.2307/2657461.

Duncan, G. J., \& Hoffman, S. D. (1985). A reconsideration of the economic consequences of marital dissolution. Demography, 22(4), 485-497. https://doi.org/10.2307/2061584.

Duvander, A. -Z., \& Viklund, I. (2014). Kvinnors och mäns föräldraledighet. In SOU 2014:28 (Ed.), Lönsamt arbete? Familjeansvarets fördelning och konsekvenser [Profitable work? Distribution and consequences of family responsibility] (Governmental report for the delegation for gender equality in working life, pp. 23-61). Stockholm: Fritzes.

Duvander, A.-Z., Ferrarini, T., \& Johansson, M. (2015). Familjepolitik för alla? En ESO-rapport om föräldrapenning och jämställdhet [Family policy for everyone? An ESO report on parental benefit and gender equality] (Rapport till Expertgruppen för studier i offentlig ekonomi 2015: 5). Stockholm: Elanders Sverige AB. 
England, P., Bearak, J., Budig, M. J., \& Hodges, M. J. (2016). Do highly paid, highly skilled women experience the largest motherhood penalty? American Sociological Review, 81(6), 1161-1189. https://doi.org/10.1177/0003122416673598.

Eriksson, H. (2018). Taking turns or having it all: Care trajectories of dual-caring couples. European Journal of Population, 35(1), 191-219. https://doi.org/10.1007/s10680-018-9473-5.

Evertsson, M. (2004). Formal on-the-job training: A gender-typed experience and wage-related advantage? European Sociological Review, 20(1), 79-94. https://doi.org/10.1093/esr/20.1.79.

Evertsson, M. (2016). Parental leave and careers: Women's and men's wages after parental leave in Sweden. Advances in Life Course Research, 29, 26-40. https://doi.org/10.1016/j. alcr.2016.02.002.

Evertsson, M., \& Boye, K. (2016). The gendered transition to parenthood: Lasting inequalities in the home and in the labor market. In R. A. Scott \& M. C. Buchmann (Eds.), Emerging trends in the social and behavioral sciences: An interdisciplinary, searchable, and linkable resource (pp. 1-16). Wiley Online Library.

Ferrarini, T. (2006). Parental leave institutions in eighteen post-war welfare States. Doctoral Dissertation, Stockholm University, Swedish Institute for Social Research.

Föräldraledighetslag. [Parental Leave Act]. (1995). Government Offices of Sweden. SFS 1995: 584. https://www.riksdagen.se/sv/dokument-lagar/dokument/svensk-forfattningssamling/ foraldraledighetslag-1995584_sfs-1995-584. Accessed 20 July 2019.

Gangl, M., \& Ziefle, A. (2009). Motherhood, labor force behavior, and women's careers: An empirical assessment of the wage penalty for motherhood in Britain, Germany, and the United States. Demography, 46(2), 341-369. https://doi.org/10.1353/dem.0.0056.

Glauber, R. (2018). Trends in the motherhood wage penalty and fatherhood wage premium for low, middle, and high earners. Demography, 55(5), 1663-1680. https://doi.org/10.1007/ s13524-018-0712-5.

Gornick, J., \& Meyers, M. (2003). Families that work: Policies for reconciling parenthood and employment. New York: Russell Sage Foundation.

Heuveline, P., Timberlake, J. M., \& Furstenberg, F. F. (2003). Shifting childrearing to single mothers: Results from 17 western countries. Population and Development Review, 29(1), 47-71. https://doi.org/10.1111/j.1728-4457.2003.00047.x.

Hodges, M. J., \& Budig, M. J. (2010). Who gets the daddy bonus? Organizational hegemonic masculinity and the impact of fatherhood on earnings. Gender \& Society, 24(6), 717-745. https:// doi.org/10.1177/0891243210386729.

Hoem, J. M. (1997). Educational gradients in divorce risks in Sweden in recent decades. Population Studies, 51(1), 19-27. https://doi.org/10.1080/0032472031000149696.

Holden, K. C., \& Smock, P. J. (1991). The economic costs of marital dissolution: Why do women bear a disproportionate cost? Annual Review of Sociology, 17(1), 51-78. https://doi. org/10.1146/annurev.so.17.080191.000411.

Jansen, M., Mortelmans, D., \& Snoeckx, L. (2009). Repartnering and (re)employment: Strategies to cope with the economic consequences of partnership dissolution. Journal of Marriage and Family, 71(5), 1271-1293. https://doi.org/10.1111/j.1741-3737.2009.00668.x.

Kennerberg, L. (2007). Hur förändras kvinnors och mäns arbetssituation när de får barn? [How do women's and men's work situations change when they have children?] (Rapport 2007:9). Uppsala: IFAU - Institutet för arbetsmarknadspolitisk utvärdering.

Maldonado, L. C., \& Nieuwenhuis, R. (2015). Family policies and single parent poverty in 18 OECD countries, 1978-2008. Community, Work \& Family, 18(4), 395-415. https://doi.org/1 0.1080/13668803.2015.1080661.

Mandel, H., \& Semyonov, M. (2005). Family policies, wage structures, and gender gaps: Source of earnings inequality in 20 countries. American Sociological Review, 70(6), 949-967. https:// doi.org/10.1177/000312240507000604.

McKeever, M., \& Wolfinger, N. H. (2001). Reexamining the economic costs of marital disruption for women. Social Science Quarterly, 82(1), 202-217. https://doi.org/10.1111/0038-4941.00018. 
McManus, P. A., \& DiPrete, T. A. (2001). Losers and winners: The financial consequences of separation and divorce for men. American Sociological Review, 66(2), 246-268. https://doi. org/10.2307/2657417.

Mincer, J., \& Polacheck, S. (1974). Family investments in human capital: Earnings of women. Journal of Political Economy, 82(2), 76-108. https://doi.org/10.1086/260293.

Mortelmans, D., \& Defever, C. (2018). Income trajectories of lone parents after divorce: A view with Belgian register data. In L. Bernardi \& D. Mortelmans (Eds.), Lone parenthood in the life course (pp. 191-211). Cham: Springer. https://doi.org/10.1007/978-3-319-63295-7.

Musick, K., Bea, M. D., \& Gonalons-Pons, P. (2017). Cross-national comparisons of his and her work and earnings following parenthood. Paper presented at the female-breadwinner families workshop, December 12-13, London.

Nieuwenhuis, R., \& Maldonado, L. C. (2018). The triple bind of single-parent families. Resources, employment and policies to improve well-being. Bristol: Policy Press.

Nylin, A.-K., Musick, K., Billingsley, S., Duvander, A.-Z., \& Evertsson, M. (2019). Trends over time in his and her earnings following parenthood in Sweden. Stockholm Research Reports in Demography 2019:03.

Ohlsson-Wijk, S., Brandén, M., \& Duvander, A.-Z. (2018). Committing to marriage? The role of marriage attitudes and gender equality among young cohabiters in Sweden. Stockholm research reports in demography 2018-11.

Ozawa, M. N., \& Yoon, H.-S. (2002). The economic benefit of remarriage: Gender and income class. Journal of Divorce and Remarriage, 36(3), 21-39. https://doi.org/10.1300/J087v36n03_02.

Page, M. E., \& Stevens, A. H. (2004). The economic consequences of absent parents. Journal of Human Resources, 39(1), 80-107. https://doi.org/10.2307/3559006.

Perelli-Harris, B., \& Sánchez Gassen, N. (2012). How similar are cohabitation and marriage? Legal approaches to cohabitation across Western Europe. Population and Development Review, 38(3), 435-467. https://doi.org/10.1111/j.1728-4457.2012.00511.x.

Petersen, T., Penner, A. M., \& Høgsnes, G. (2014). From motherhood penalties to husband premia: The new challenge for gender equality and family policy, lessons from Norway. American Journal of Sociology, 119(5), 1434-1472. https://doi.org/10.1086/674571.

Ruhm, C. R. (1998). The economic consequences of parental leave mandates: Lessons from Europe. The Quarterly Journal of Economics, 113(1), 285-317. https://doi. org/10.1162/003355398555586.

Schiratzki, J. (2008). Mamma och Pappa inför Rätta. [Mom and dad in court]. Stockholm: Iustus.

Selin, H. (2014). The rise in female employment and the role of tax incentives: An empirical analysis of the Swedish individual tax reform of 1971. International Tax and Public Finance, 21(5), 894-922. https://doi.org/10.1007/s10797-013-9283-y.

Sigle-Rushton, W., \& Waldfogel, J. (2007). Motherhood and women's earnings in AngloAmerican, continental European, and Nordic countries. Feminist Economics, 13(2), 55-91. https://doi.org/10.1080/13545700601184849.

Statistics Sweden. (2014). Olika familjer lever på olika sätt - om barns boende och försörjning efter en separation [Different families live in different ways - about children's living and livelihood after a separation]. Demografiska rapporter, 2014: 1. Örebro: Statistics Sweden.

Statistics Sweden. (2016). Women and men in Sweden 2016: Facts and figures. Örebro: Statistics Sweden.

Statistics Sweden, Household's finances. (2014). Disposable income by type of household, 2011-2017. Median value in SEK thousands, 2017 prices. Statistics Sweden. http://www.scb. se/he0110-en. Accessed 31 May 2019.

Swedish National Agency for Education. (2018). Tabell 2B. Inskrivna barn 2007-2018. Andel av alla barn i befolkningen [Table 2B. Children registered in pre-school. Share of all children]. National Agency for Education. https://www.skolverket.se/skolutveckling/statistik. Accessed 31 May 2019.

Swedish Social Insurance Agency. (2009). Ensamstående föräldrars ekonomiska situation [Single parents' economic situation]. Social Insurance Report, 2009(4). 
Thalberg, S. (2013). Students and family formation. Studies on educational enrolment and childbearing in Sweden. Doctoral dissertation, Stockholm University, Department of Sociology.

Thomson, E. (2005). Partnerships \& parenthood: A comparative view of cohabitation, marriage, and childbearing. In A. Booth \& A.-C. Crouter (Eds.), The new population problem: Why families in developed countries are shrinking and what it means (pp. 129-150). Mahwah: Taylor \& Francis.

Uunk, W. (2004). The economic consequences of divorce for women in the European Union: The impact of welfare state arrangements. European Journal of Population, 20(3), 251-285. https:// doi.org/10.1007/s10680-004-1694-0.

Wadsby, M., Priebe, G., \& Svedin, C. G. (2014). Adolescents with alternating residence after parental divorce: A comparison with adolescents living with both parents or with a single parent. Journal of Child Custody, 11(3), 202-215. https://doi.org/10.1080/15379418.2014.943448

Weiss, R. S. (1984). The impact of marital dissolution on income and consumption in singleparent households. Journal of Marriage and the Family, 46(1), 115-127. https://doi. org/10.2307/351870.

Open Access This chapter is licensed under the terms of the Creative Commons Attribution 4.0 International License (http://creativecommons.org/licenses/by/4.0/), which permits use, sharing, adaptation, distribution and reproduction in any medium or format, as long as you give appropriate credit to the original author(s) and the source, provide a link to the Creative Commons license and indicate if changes were made.

The images or other third party material in this chapter are included in the chapter's Creative Commons license, unless indicated otherwise in a credit line to the material. If material is not included in the chapter's Creative Commons license and your intended use is not permitted by statutory regulation or exceeds the permitted use, you will need to obtain permission directly from the copyright holder.

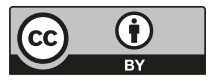

